\title{
Comperation of Porang Flour (morphophallus muelleri) Purification Method : Conventional Maceration (gradient ethanol leaching) and Ultrasonic Maceration Method using Response Surface Methodology
}

\author{
Anni Faridah \\ ${ }^{\#}$ Faculty of Tourism and hospitality, Padang State University, Padang, West Sumatra 25131, Indonesia \\ E-mail: faridah.anni@gmail.com
}

\begin{abstract}
Porang flour (Amorphophallus muelleri) contained fairly high of glucomannan and slightly orange white colour whereas also contained oxalates which are toxic to human. This toxic property caused unacceptable for food applications. This systematic study was undertaken to compare two of the optimizations method of flour porang purification i.e. using various of ethanol concentration washing (conventional maceration) and ultrasonic maceration method to obtain high glucomannan levels and high viscosity with low calcium oxalate and bright white colour of flour. Response surface methodology (RSM), Central Composite Design (CCD) on three independent variables (leaching time (X1), stirring speed (X2) and the ratio of solvent to flour (X3)) for the conventional maceration and two independent variables ( time leaching (X1) and and the ratio of solvent to flour (X2)) for ultrasonic maceration, has been done. Response analyzed on glucomannan levels, viscosity, concentration of calcium oxalate, and brightness. Response has a quadratic model except the brightness of the colours of the linear model in both maceration. The ultrasonic maceration obtained faster washing time i.e. 3 hours, 53 minutes and 18 compare than the conventional maceration and used more less solvent and get a high levels of glucomannan response values, viscosity values, well white brightness colour and a low levels of oxalic acid value.
\end{abstract}

Keywords - porang flour; RSM; ethanol; maceration; ultrasonic

\section{INTRODUCTION}

Glucomannan is a stongly hidrocolloid water-soluble polysaccharide, can establish a gel, high viscosity property, low in calories, so it has high potential to be developed in the food and non food industry [1]. Purification the porang flour using mechanical method resulted $67.02 \%$ of glucomannan and $0.398 \%$ of calcium oxalate [2]. Glucomannan application on food products can be made by purifying the glucomannan that can produce high level of glucomannan, high viscosity, reduced calcium oxalate (almost free), obtaining bright white colour flour which may elevate the economic value of the porang flour itself. Glucomannan purification can be optimized by use chemicals by using conventional leaching maceration and ultrasonic maceration technique.

Leaching can be done by adding some chemicals that can dissolve or precipitate any impurities or undesirable compounds except glucomannan which exist in porang flour. The solvent selection was base on its properties such as selectivity, recovery easiness, coefficients, and its chemical activity [3]. Porang flour can be extracted using water miscible solvent like ethanol that could dissolved in water, but will not cause glucomannan to swell. The use of water miscible solvents will not make glucomannan to expand and its impurities will be easy to separate [4]. The ethanol washing process can dissolve the non-glucomannan compounds due to its high polarity is fit to dissolved resins, fats, oils, fatty acids, carbohydrates and other organic compounds [5].

Porang flour laundering mechanism by using ethanol solution can be assumed as a leaching process (solid - liquid extraction), with retrieval some soluble compounds in the solid surface by using liguid material (solvent) [5]. In this leaching process, the soluble compounds trapped in solids and move through the pores of the solid. Solute diffuses out from the solid surface of particles and move into the lining around the solids, then to the solution.

Smirnova rt al [6] reported that glucomannan extraction method by using alcohol precipitation is intended to produce a high purity of glucomannan. High purity of konjak flour has been purified by alcohol precipitation that wash the konjac flour out from soluble starch. After leaching process, yield of rendemen contained high levels of gum and unwanted compounds including sulfur dioxide can be reduced [7]. 
Conventional leaching maceration method was different from ultrasonic maceration. Ultrasonic leaching will increase the permeability of cell walls, forming cavitation (holes) and improve mechanical stress. The mechanical effect of ultrasound led to increase the penetration of the solvent into the cells and improves mass transfer [8] [9], thus this mechanism will make the obtained result of ultrasonic maceration aplication to the cell [10]. Leaching ultrasonic maceration will be faster, but expensive compared to conventional leaching maceration.

The main advantage of using ultrasonic leaching are more time-efficiency and improved yield [10], [11], [9]. [12] also concluded that using fast, non-destructive, accurate, automated of ultrasonic measurement can be applied into the laboratory even in on-line measurement. Ultrasonic extraction requires less time with high productivity, reduce the amount of solvent and lower operational costs [13]. [14] mentioned that ultrasonic produces cell disruption, particle size reduction, shortening time and increase efficiently. [15] acquired that ultrasonic extraction rate was faster (34 minutes) than the conventional method during the extraction of pectin from grapefruit peel. This study aimed to compare conventional and ultrasonic maceration method on leaching optimization of flour porang by using an ethanol solution to obtain high level of glucomannan, high viscosity, bright white colour of the flours and low content of calcium oxalate.

\section{MATERIALS AND METHODS}

\section{A. Material, Solvents and Reagents.}

Porang flour that has been used was the result of bulbs porang flouring optimization [2]. Porang (local name of konjac bulb) is native to Indonesian, size is range from 15$25 \mathrm{~cm}$ in diameter, $5-10 \mathrm{~cm}$ in height and 500-2500 $\mathrm{g}$ in weight. It was obtained from Bendo Village, Saradan Subdistrict, Regency Madiun, Indonesia. The chemicals pro analysis (p.a) purity were used: $\mathrm{NaOH}$, formic acid, concentrated $\mathrm{HCl}$ (37\%), concentrated $\mathrm{H} 2 \mathrm{SO} 4$ (95\%), $\mathrm{CaCl} 2$, ether, methyl red indicator, phenolphetaline (pp) indicator, $\mathrm{NH} 4 \mathrm{OH}$, Kjeldahl tablets, boric acid $30 \%$, sodium sulfate and dinitrosalycilicacid (DNS).

\section{B. Extraction methods}

Research design on both maseration method was the same. The difference was during application of homogenizer or stirrer with certain speed in the conventional method while ultrasonic maceration, vibrating horn system (amplitude of $300 \mathrm{~dB}$ ) and a frequency of $60 \mathrm{kHz}$ was used. The procedures, flow charts and observations applied can be seen in Figure 1.

\section{Analysis methods}

Water content was determined by weight difference after drying of samples, following the official method of [17]. Fat content was determined using a Soxhlet apparatus according to [17]. Protein content was calculated from the nitrogen content (N\% : 6.25) analyzed by Kjeldahl method. Ash was determined gravimetrically [17]. Starch content as calculated as described by [18]. Yield was calculated based on the weight of the crude porang flour to the total weight of porang used. Calcium oxalate was determined as described by [20] and glucomannan assay was conducted as described by [21]. Scanning electron microscope (SEM) (Instruction Manual FEI type Inspect S50) was used to observe microscopically on rough porang flour and leaching optimization process of porang flour was carried out using maceration method.

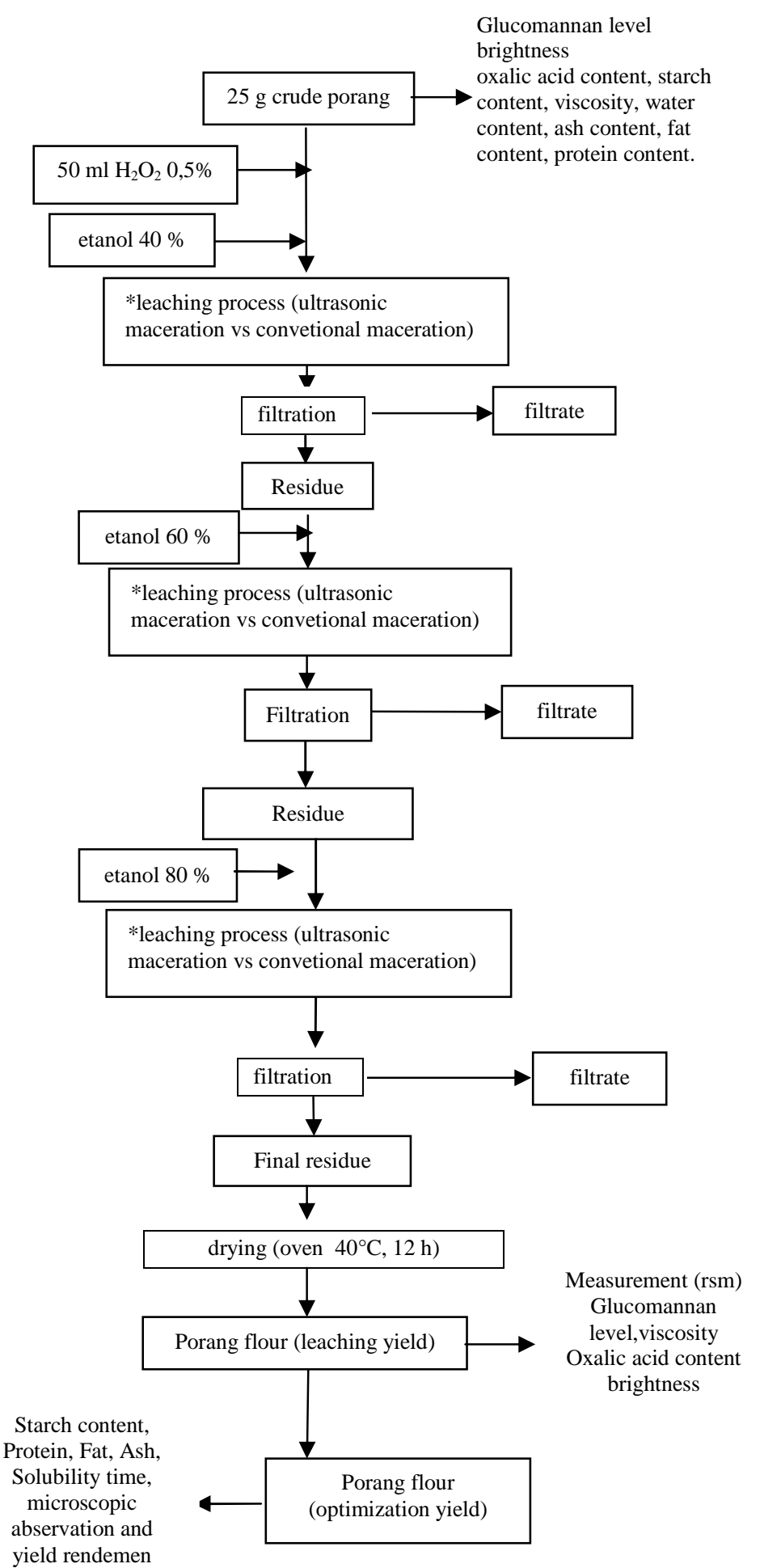

Note:*The conventional maceration using a homogenizer according to the research design (Table I) and ultrasonic maceration method using vibrating horn system $(60 \mathrm{kHz}, 300$ decibels) the research design (Table II)

Fig. 1. Flow chart of porang flour laundering using conventional maceration and ultrasonic maceration (Modified from [16]) 
The improved of glucomannan content and reduced of calcium oxalate content using by various (multi level) ethanol concentration were optimized using RSM, employing the CCD. The range and center point values of three independent variables were presented in Table 1 were based on the results of preliminary experiments on the extraction of porang flour as described under the extraction method section in this study [4]. Leaching time (X1), stirring speed (X2), and ratio of solvent ethanol toflour (X3) were chosen for independent variables

TABLE I

INDEPENDENT VARIABLES AND THEIR LEVELS USED FOR CCD ON CONVENTIONAL MACERATION

\begin{tabular}{|l|l|l|l|l|l|}
\hline \multirow{2}{*}{ Independent variables } & \multicolumn{5}{|c|}{ Levels } \\
\cline { 2 - 6 } & $\mathbf{- 1 , 6 8}$ & $\mathbf{- 1}$ & $\mathbf{0}$ & $\mathbf{+ 1}$ & $\mathbf{+ 1 , 6 8}$ \\
\hline Leachig time (h) (X1) & 2,32 & 3 & 4 & 5 & 5,68 \\
Stirring speed (rpm) (X2) & 63,64 & 200 & 400 & 600 & 736,36 \\
Ratio of solvent to flour (X3) & $1: 4.64$ & $1: 6$ & $1: 8$ & $1: 10$ & $1: 11$ \\
& & & & & .36 \\
\hline
\end{tabular}

TABLE II

INDEPENDENT VARIABLES AND THEIR LEVELS USED FOR CCD ON ULTRASONIC MACERATION

\begin{tabular}{|l|l|l|l|l|l|}
\hline \multirow{2}{*}{ Free variable } & \multicolumn{5}{|c|}{ Level of free variable } \\
\cline { 2 - 6 } & $\mathbf{- 1 , 4 1 4}$ & $\mathbf{- 1}$ & $\mathbf{0}$ & $\mathbf{+ 1}$ & $\mathbf{+ 1 , 4 1 4}$ \\
\hline Contact time (minutes) (X1) & 10,86 & 15 & 25 & 35 & 39,14 \\
Ratio (sovent : flour) (X2) & $5,17: 1$ & $6: 1$ & $8: 1$ & $10: 1$ & $10,83: 1$ \\
\hline
\end{tabular}

\section{Statistical analyses}

The responses obtained from each set of experimental design (Table 1 and 2) were subjected to multiple non-linear regressions using the Design Expert software (Version7.1, Stat-Ease Inc., Minneapolis, MN). The quality of the fit of the polynomialmodel equation was expressed by the coefficient of determination, R2 and the significances of the regression coefficient were checked by F-test and p-value.

\section{RESULT AND DISCUSSIONS}

\section{A. Fitting the model}

Response model has sequence value (sequential model of sum of squares) $\mathrm{p}<5 \%$ and quadratic. If the values of response model in order to $\mathrm{p}<5 \%$, so the quadratic model has a significant response. Response of brightness, $\mathrm{p}$ value $=$ $<5 \%$, it's a linear model. [22] also get a sequential model of sum of squares value of $p=0.0013(0.13 \%)$, which mentioned that the chances of a model error of less than 5\%, or quadratic model has a real influence on the response. [23] informed that if the value of $p<0.05$, the model was significant and has a greater influence for response compare with the other models. [24] also mentioned that the smaller of $\mathrm{p}$ value, the model will be more significant. Model selection that based on sequential sum of squares, indicated the significant model and recommended for all three responses was a quadratic $(\mathrm{P}<0.0001)$. This showed, that the chances of a model error, less than $5 \%$, or quadratic model has a real influence on the response. This applied to both of the optimized porang flour (conventional and ultrasonic maceration). However, the response model of brightness was a linear model (Table III). Quadratic model of all of three response and linear for brightness has chosen due to its value of $\mathrm{p}<5 \%$ which was better in according to the statement of [24], the significantly quadratic polynomial models on optimizing of ultrasonic leaching of water-soluble polysaccharide from Boletus edulis mycelia using RSM with a $\mathrm{p}$ value of 0.0003 .

TABLE III MODEL SELECTION

\begin{tabular}{|c|c|c|}
\hline \multirow{2}{*}{} & \multicolumn{2}{|c|}{ Purification } \\
\cline { 2 - 3 } & $\begin{array}{c}\text { Conventional } \\
\text { (4 response) }\end{array}$ & $\begin{array}{c}\text { Ultrasonic } \\
\text { (4 Response) }\end{array}$ \\
\cline { 2 - 3 } MODEL & $\begin{array}{c}\text { Quadratic, } \\
\text { Linear (colour) }\end{array}$ & $\begin{array}{c}\text { Quadratic, } \\
\text { Linear (colour) }\end{array}$ \\
Value of p Model & $<0,003$ & $<0,02$ \\
Value p Lack of fit & $>0,05$ & $>0,05$ \\
Value of p R & $>0,81$ & $>0,85$ \\
Value of p Adj $\mathrm{R}^{2}$ & $>0,75$ & $>0,75$ \\
\hline
\end{tabular}

According to lack of fit test, recommended model on both macerations were quadratic for glucomannan levels, viscosity, concentration of oxalic acid and linear for brightness. For a comparison with similar technique, [25] mentioned that the model will be significant if lack of fit test values $>0.05$.

The R2 value, that close to 1 , illustrates the high correlation between the observed and predicted values [26]. [27] mentioned that the value of $\mathrm{R} 2=0.58$ was quite good and acquire an acceptable models. [28] informed that the value of $\mathrm{R} 2>0.75$ indicates the model accuration. The R2 value on both optimization of flour porang results was > 0.75 (Table III). This means that the variable such as washing time, stirring speed and the ratio of solvent: flour have affected to the diversity of responses for glucomannan levels, viscosity, concentration of oxalic acid and brightness.

\section{B. Response optimal point and verification}

Figure 2 shows that time variable, stirrer speed and the ratio of solvent's provided the optimum point to the interaction response. In this study, the expected result was the porang flour that will has higher levels of glucomannan with maximum viscosity values, low oxalate levels and good acceptable of brightness. The optimum solution point obtained from Design Expert computational results are shown in Tables IV and V.

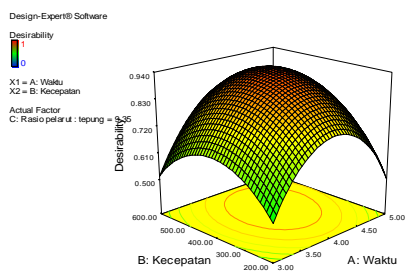

Conventional maceration rensponse

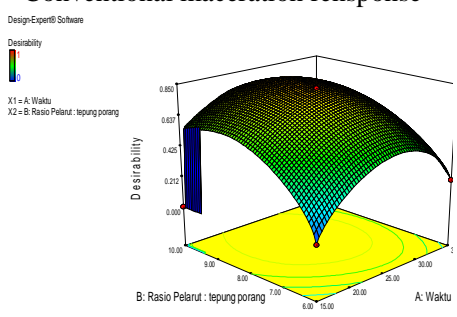

Ultrasonic maceration rensponse

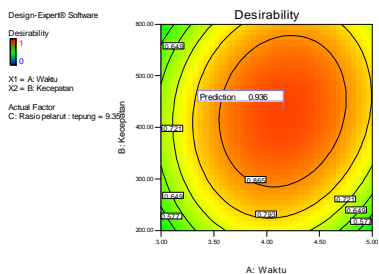

Conventional maceration contour

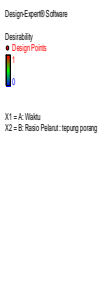

Ultrasonic maceration contour
Fig. 2. Surface and Contour responese of Variable Optimum Point towards Interaction Response 
Canonical analysis to quadratic polynomial models were used to determine the shape and the curve of response surface, as well as the location of a stationary point or the optimum point of the surface response and to determine whether the response will be minimum or maximum [29]. The actual value for a stationary point obtained from canonical analysis were 4.16 hours for contact time, 434 rpm for stirring speed and 9.35: 1 for the ratio of solvent: flour of (Table IV), for the results of conventional and ultrasonic maceration is 25.10 minutes. While the point optimum of solvent ratio variables: porang flour is $8.65: 1$ or in solution property is $216.25 \mathrm{ml}$ (Table V).

Table IV also shows the predicted response of glucomannan levels, viscosity, oxalic acid and the brightness on a optimum conditions of conventional maceration respectively for $79.38 \%, 9701.09 \mathrm{cPs}, 0.076 \%$, and 53.94 . This condition was the best condition to obtain the highest levels of glucomannan and viscosity, low levels of oxalic acid and the quite well brightness of porang conventional laundering maceration flour. Thus, for the results of the optimization of ultrasonic maceration, optimum solution point variables, obtained the optimum response values of glucomannan levels $(85.74 \%)$, oxalic acid content $(0.044 \%)$, the viscosity (13970.7 cPs), and 59.78 of brightness. The optimum solution point obtained from Design Expert computational results that are shown in Table V.

TABLE IV.

Optimum Solutions Point Of SElected Conventional MaCERATion Design ExPert Calculation Results

\begin{tabular}{|c|c|c|c|c|c|c|c|c|c|}
\hline $\begin{array}{c}\text { Sour } \\
\text { ce }\end{array}$ & Washing time (h) & Stirring speed (rpm) & $\begin{array}{c}\text { Ratio (solvent: } \\
\text { flour) }\end{array}$ & $\begin{array}{l}\text { GM con } \\
\text { tent }(\%)\end{array}$ & $\begin{array}{c}\text { Visco } \\
\text { sity (cPs) }\end{array}$ & Oxalat acid $(\%)$ & Brightness & Desirability & Ket. \\
\hline Prediction & 4,16 & 434,04 & $9,35: 1$ & 79,38 & 9701,09 & 0,076 & 53,94 & 0,936 & Selected \\
\hline Verification & 4,16 & 434 & $9,35: 1$ & 80,17 & 9733,33 & 0,077 & 53,95 & - & - \\
\hline & \multicolumn{3}{|c|}{ The difference } & 0,79 & 32,24 & 0,001 & 0,01 & - & - \\
\hline & \multicolumn{3}{|c|}{ The diversity value (\%) } & 0,99 & 1,36 & 1,31 & 0,89 & & \\
\hline
\end{tabular}

source : [21]

TABLE V

OPtIMUM SOlutions Point OF SELECTEd Ultrasonic MACERATION DESIGN EXPERT CALCULATION RESULTS

\begin{tabular}{|c|c|c|c|c|c|c|c|}
\hline source & $\begin{array}{c}\text { Time } \\
\text { (minutes) }\end{array}$ & $\begin{array}{c}\text { Ratio } \\
\mathbf{S}: \mathbf{f} \\
(\mathbf{v} / \mathbf{b})\end{array}$ & $\begin{array}{c}\text { GM } \\
\text { content } \\
(\%)\end{array}$ & $\begin{array}{c}\text { Axalic } \\
\text { acid } \\
(\%)\end{array}$ & $\begin{array}{c}\text { viscosity } \\
\text { (cPs) }\end{array}$ & $\begin{array}{c}\text { Bright } \\
\text { ness }\end{array}$ & Desirability \\
\hline Design & 25,10 & $\begin{array}{c}8,65 \\
1 \\
\end{array}$ & 85,74 & 0,044 & 13970,7 & 59,78 & 0,843 \\
\hline Verification & 25,10 & $\begin{array}{c}8,65 \\
1\end{array}$ & 84,37 & 0,045 & 13750 & 60,38 & - \\
\hline \multicolumn{3}{|c|}{ The difference } & 1,37 & 0,001 & 220,7 & 1,39 & - \\
\hline \multicolumn{3}{|c|}{ The diversity value (\%) } & 1,62 & 2,22 & 1,6 & 2,33 & - \\
\hline
\end{tabular}

The verification of optimum results should be done as an evidence that the optimum point solutions that provided by the independent variables. Design Expert program surely gives a response results in accordance with the optimum response that has been determined by the program and optimal absolutely. Verification step was done by comparing the value of the research response analysis with response value calculation results Design Expert software. The percentage of differences in the value of each response was not wide and calculation results value of the verification almost closed to Design Expert calculation. The difference of predictive value with the research result was not more than $5 \%$, that indicates the model was quite appropriate for the extraction process [30].

Washing optimization of porang flour with ultrasonic maceration were fast ( 25 minutes, 6 seconds), less solvent (8.65) and generate of glucomannan levels, viscosity and brightness also reduce of calcium oxalate (Table VI). [31] reported the effect of mechanical ultrasonic extraction, due ultrasonic energy waves cause fluid penetration force more powerful to the inside of the extracted cells compared with classical extraction methods. [10] emphasized that the main advantage of the use of ultrasonic extraction are an efficiency, faster extraction times and improved results. Ultrasonic leaching requires less time with high productivity, that can reduce the amount of solvent and lower operational costs [14]. [15] informed that the ultrasound produces cell disruption, particle size reduction, shortening the time and more efficiently. [16] acquire ultrasonic extraction rate several times faster (30 minutes) rather than maceration (24 hours) on the extraction of steroids and triterpenoids of Chresta spp. Ultrasonic extraction method is better than the conventional methods of extraction and ultrasonic vibrating horn is better than an ultrasonic bath [32]

TABLE VI

The DifFerences VALUES OF VARIABLES AND RESPONSE OF CONVENTIONAL AND ULTRASONIC MACERATION OPTIMIZATION LAUNDERING

\begin{tabular}{|l|c|c|c|c|c|c|}
\hline Method & $\begin{array}{c}\text { Washing } \\
\text { time } \\
\text { (minutes) }\end{array}$ & $\begin{array}{c}\text { Solvent } \\
\text { ratio }\end{array}$ & $\begin{array}{c}\text { Gluco } \\
\text { mannan } \\
(\boldsymbol{\%})\end{array}$ & $\begin{array}{c}\text { Visko } \\
\text { sity } \\
(\mathbf{c ~ P s})\end{array}$ & $\begin{array}{c}\text { Calcium } \\
\text { oxalate } \\
(\boldsymbol{\%})\end{array}$ & $\begin{array}{c}\text { Bright } \\
\text { ness }\end{array}$ \\
\hline $\begin{array}{l}\text { Conven } \\
\text { tional }\end{array}$ & 246 & 9,35 & 80,17 & 9733 & 0,109 & 53,94 \\
\hline $\begin{array}{l}\text { Ultra } \\
\text { sonic }\end{array}$ & 25,1 & 8,65 & 84,37 & 13750 & 0,064 & 60,38 \\
\hline
\end{tabular}

\section{Physicochemical analysis of optimized porang flour}

Significantly increased levels of glucomannan from $67.02 \%$ became $80.17 \%$ (conventional) and $84.37 \%$ (ultrasonic) is shown on Table VII. Ethanol washed and the use of ultrasonic can dissolve more impurities compounds and non glucomannan components higher than conventional maceration. It also can be seen in Figure 3 that observation 
with a light microscope by a magnification of $100 \mathrm{x}$ and reinforced by SEM-EDAX (Figure 4). Observations on conventional porang flour starch surface showed that non glucomannan granules were more than ultrasonic maceration porang flour.

Conventional porang flour's viscosity $(9733,33 \mathrm{cPs})$ was lower than ultrasonic maceration (13750 cPs). High and low viscosity of porang flour were closely related to levels of contained glucomannan. The washing process also can increase glucomannan levels and decline the starch, protein, fat, ash contents and calcium oxalate contrations. [33] mentioned that the purification process of konjac flour by washing with ethanol is very effective in reducing impurity components that located on the surface $s$ glucomannan granule. The viscosity increasement was associated with the increase glucomannan. Washing process with ethanol and ultrasonic maceration, high levels of glucomannan will lead the viscosity elevation. [34] concluded that glucomannan has a high molecular weight (> $300 \mathrm{kDa})$, where it can form a thick solution pseudoplastis. This is also supported by a statement of [16], that glucomannan in water at room temperature will give high viscosity and form a gel when added lime.

TABLE VII

Physico-Chemical ANALysis Of Optimized Porang Flour

\begin{tabular}{|c|c|c|c|}
\hline \multirow[b]{2}{*}{ Parameter } & \multirow[b]{2}{*}{ Sample } & \multicolumn{2}{|c|}{ Data } \\
\hline & & $\begin{array}{l}\text { Conventional } \\
\text { maseration } * *\end{array}$ & $\begin{array}{c}\text { Ultrasonic } \\
\text { maceratio } \\
\text { n }\end{array}$ \\
\hline $\begin{array}{l}\text { Calcium oxalate } \\
(\%)(\%)\end{array}$ & 0,398 & 0,109 & 0,064 \\
\hline Glucomannan (\%) & 67,02 & 80,17 & 84,37 \\
\hline Water content $(\%)$ & 12,17 & 14,11 & 8,99 \\
\hline Ash content $(\%)$ & 2,63 & 0,331 & 0,32 \\
\hline Starch content $(\%)$ & 2,70 & 1,25 & 0,53 \\
\hline Protein $(\%)$ & 2,35 & 0,87 & 0,26 \\
\hline Fat (\%) & 1,49 & 0,47 & 0,53 \\
\hline Brightness & $50,76^{*}$ & $53,93^{*}$ & $60,38 *$ \\
\hline Viskosity (c.Ps) & 6300 & 9733,33 & 13750 \\
\hline Rendemen (\%) & 62,71 & 89,87 & 77,41 \\
\hline Solubility rate (sec) & 1205 & 812 & 772 \\
\hline $\begin{array}{l}\text { Residue of } \mathrm{H}_{2} \mathrm{O}_{2} \\
(\%)\end{array}$ & - & 0,012 & 0,007215 \\
\hline
\end{tabular}

Description: * use no unit, where a value of 100 is assumed as pure white. ** [21]

The optimization process of conventional maceration method for reducing calcium oxalate also shown an interesting result. Decreased levels of calcium oxalate from $0.398 \%$ into $0.109 \%$ (conventional) and $0.064 \%$ (ultrasonic) was due to the property of the miscible non polar components that contacted with high concentrations of ethanol with stirring and cavitation support. This reduction of contained calcium oxalate caused by its solubility in ethanol. [35] stated that the oxalic acid is widely precipitated in the light fraction (tobiko) of porang flour that containing impurities compounds (calcium oxalate, starch, protein) and with a small particle size (less than $1 \times 10-2 \mathrm{~mm}$ ), that would be lost with ethanol washery.

Optimized porang flour by ultrasonic maceration has brightness value $(60,38)$ higher than conventional $(53,93)$ and control sample $(50,76)$. The enhancement of brightness due to sonolisis process on ultrasonic maceration. According to [9], ultrasonic can cause sonolisis in water, resulting in $\mathrm{H}$ + and radical $\mathrm{HO}^{-}$, thus generated the hydrogen peroxide. Hydrogen peroxide can oxidize the color pigments in porang flour which will provide brighter flour color. While [36] explained that hydrogen peroxide has the ability to form reactive free radicals that react with organic molecules and oxidize macromolecules, and break it down into smaller molecules. The longer of washing time, the longer of the sonolisis process and the oxidation process will be better, thus the degree of white flour also enhancing.

Ultrasonic process also helped to eliminate impurities compounds that cause the dark colour of flour. Effects of ultrasonic cavitation will generate fractures and help break down the cell walls and increase the penetration of ethanol into the cell [37]; [38], so that the impurities that exist on the surface granules glucomannan can be detached, diffuse out of the cell surface, and easily dissolved in ethanol. The longer with the washing time, more impurity components were separated from the granules glucomannan, that make brighter surface of flour.

Residual of hydrogen peroxide in conventional and ultrasonic optimized porang flour were $0,012 \%$ and $0.007215 \%$ ( $120 \mathrm{ppm}$ and $72.15 \mathrm{ppm}$ ) respectively (Table VII). This residual is in safe consideration for consumption because it does not exceed the maximum limit hydrogen peroxide residues on food. [39] reported that FDA allowed the maximum of hydrogen peroxide residue in food is amount of $500 \mathrm{ppm}$

Optimized porang flour solubility rate by using ultrasonic maceration flour was faster $(772 \mathrm{sec})$ than the conventional $(812 \mathrm{sec})$ and control sample $(1205 \mathrm{sec})$. The purity of glucomannan was indicated to enhance the rate of flour dissolution. (Table VII).

Microscopic observations of the granules showed that the deployment of impurities in ultrasonic maceration optimization was less than the conventional maceration due to the effectivity of ethanol solvent in agreement with [40].

Observation then continued by analyzing the granules element in a field of $20 \mu \mathrm{m}$ plain using SEM-EDAX as shown in Figure 4. Figure 3 and 4 (a) indicates that the ultrasonic maceration or convetional maceration has ability to clean the impurities that covered of glucomannan granule surface. Figure 4 (b) is the spectrum of elements forming granules consisting of carbon, oxygen, potassium, calcium and chlorine with their composition as can be seen in Table VIII. Ultrasonic maceration method obtained cleaner granules compare with conventional maceration and samples, that make the granule surface texture become more rough and bumpy. While the high imputiry of flour will looked contain needle-shaped crystals due to presence of calcium oxalate (Figure 5). [33] and [41] also found oxalic acid crystals in the konjac flour with needle shaped. 


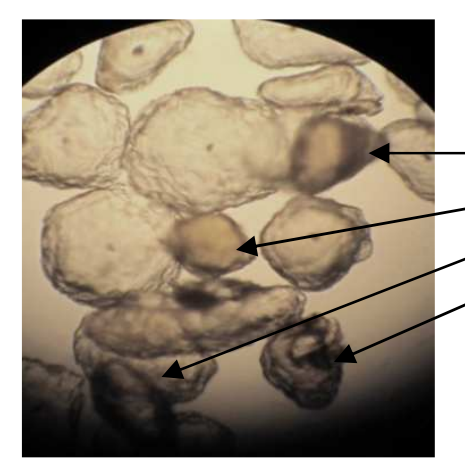

Control sample

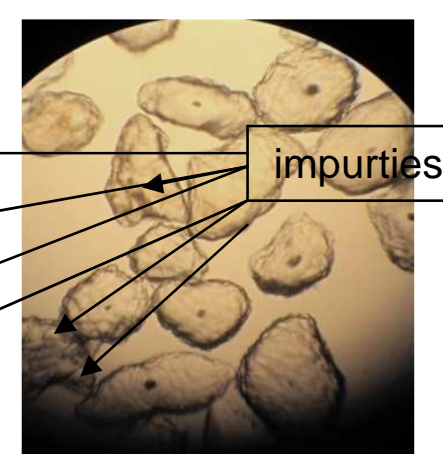

Conventional maceration*

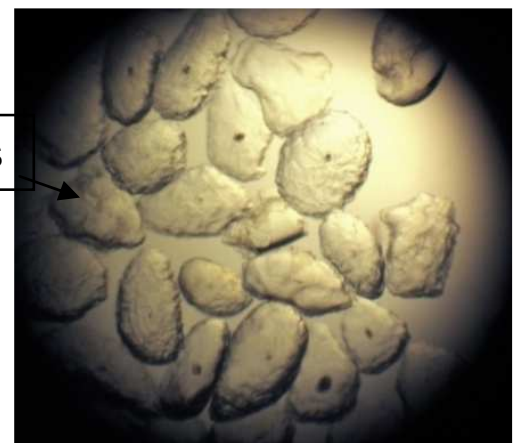

Ultrasonic maceration

Fig.3 Light microscope magnification of $100 \mathrm{x}$ observation of porang flour * [21]

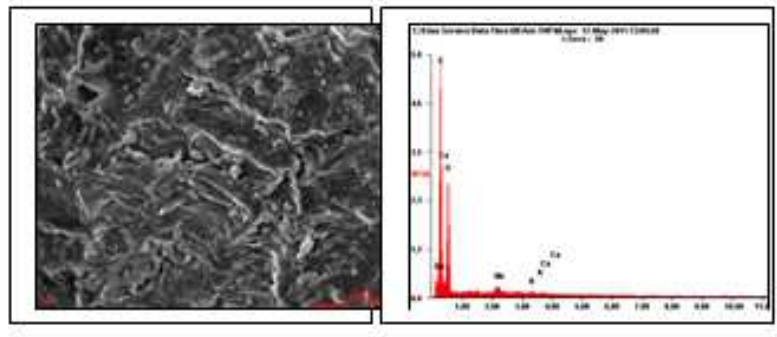

\begin{tabular}{|ll|}
\hline A Control (mechanical sample) & b \\
\hline
\end{tabular}

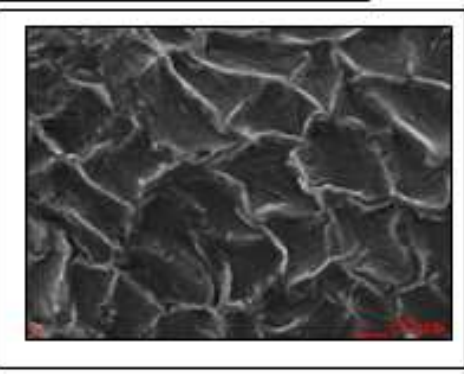

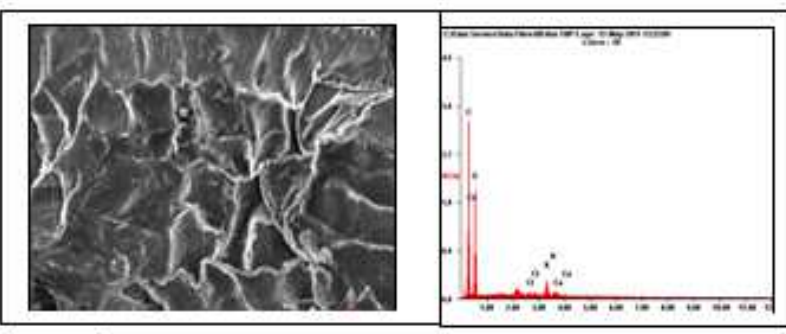

conventional macaration

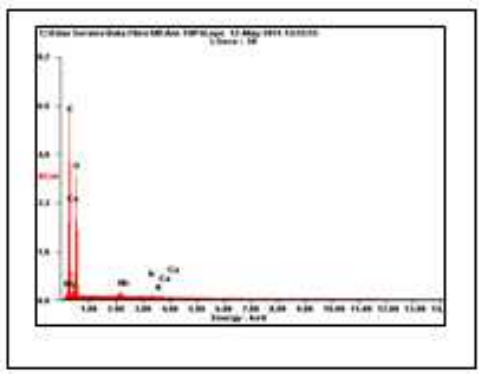

b

Fig. 4 Glucomannan garanule size at $20 \mu \mathrm{m}$ (a) Spectrum Shaping Elements granules (b). Porang flour optimization results purification

TABLE VIII

COMPOSITION OF Forming ElEMENTS OF PORANFG Flour ON Figure 4.

\begin{tabular}{|c|c|c|c|}
\hline \multicolumn{2}{|c|}{ Mechanical (control sample) } & \multicolumn{2}{|c|}{ Conventional maceration } \\
\hline Elements & $\%$ & Elements & $\%$ \\
\hline $\mathrm{C}$ & 56,75 & $\mathrm{C}$ & 61,94 \\
\hline $\mathrm{O}$ & 39,79 & $\mathrm{O}$ & 36,01 \\
\hline $\mathrm{Cl}$ & 0,30 & $\mathrm{Cl}$ & 1,44 \\
\hline $\mathrm{K}$ & 2,48 & $\mathrm{~K}$ & 0,38 \\
\hline $\mathrm{Ca}$ & 0,68 & $\mathrm{Ca}$ & 0,23 \\
\hline \multicolumn{4}{|c|}{ Ultrasonic maceration } \\
\hline & Elements & $\%$ & \\
\hline & $\mathrm{C}$ & 57,50 & \\
\hline & $\mathrm{O}$ & 40,75 & \\
\hline & $\mathrm{Cl}$ & 1,24 & \\
\hline & $\mathrm{K}$ & 0,35 & \\
\hline & $\mathrm{Ca}$ & 0,16 & \\
\hline
\end{tabular}

Glucomannan forming elements are carbon, oxygen and hydrogen. The hydrogen was not detected by using EDAX analysis. Heigh levels of glucomannan, make the element carbon and oxygen also higher, while other elements become lower (Table VIII). The calcium that suspected as a sharper of the calcium oxalate allegedly lower in connection with higher levels of glucomannan. The percentage levels of calcium and oxalate in the mehanical control sample, conventional and ultrasonic maceration respectively are $(0.398 \%$ and $0.68 \%),(0.109 \%$ and $0.23 \%)$ and $(0.064 \%$ and $0,16 \%$ ) with similiarity tandency. Glucomannan granule is very strong compared to the other components of the granules. This phenomenon due to the ultrasonic cavitation, the expansion cycle can lead aincreasing of pressure and temperatures, which can accelerates the purification process of glucomannan 


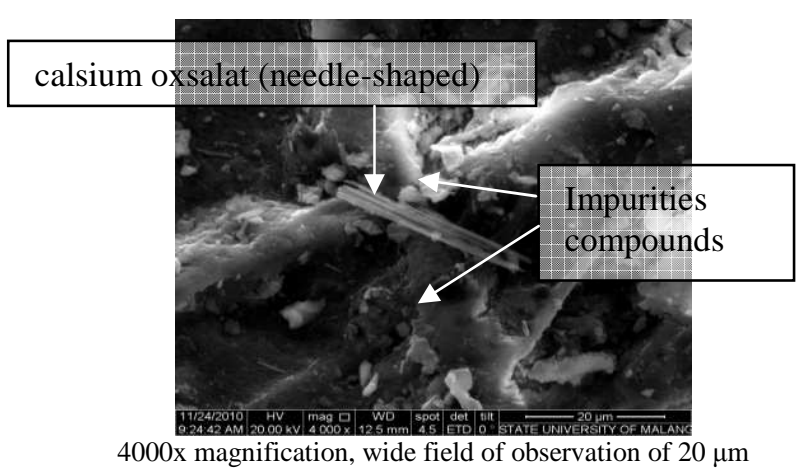

Fig. 5 SEM observation of needle-shaped oxalic acid crystals

\section{IV.CONCLUSIONS}

Purification process using ethanol with conventional maceration can increase glucomannan levels (16.4\%), viscosity value (32.7\%), brightness (5.9\%) and reduce other components including calcium oxalate levels as $263.6 \%$. The washing time, stirring speed and the ratio of solvent affected to the response of glucomannan levels, viscosity, concentration of oxalic acid and brightness. Optimal conditions were obtained, namely the washing time is 4.16 hours or 246 minutes, stirring speed of $434.04 \mathrm{rpm}$ and solvent ratio of 9.35. In optimum conditions, the response glucomannan levels, viscosity, concentration of calcium oxalate and brightness of consecutive prediction results are $79.38 \%, 9701.09 \mathrm{cPs}, 0.108 \%$ and 53.94 while the results of verification are $80.17 \%$ respectively, 9733.33 c.Ps, $0.109 \%$ and 53.95.

Purifiation by ultrasonic maceration method also shows that the washing time and the ratio of solvent: flour affected to the response of glucomannan levels, viscosity, oxalic acid levels and brightness. Optimization conditions obtained, the washing time is 25 minutes 6 seconds and the ratio of solvent: 8.65 porang flour. In optimum conditions the response of glucomannan levels is $85.74 \%, 0.044 \%$ of oxalate levels, $13970.7 \mathrm{cPs}$ the value of viscosity, and 59.78 of brightness. For the verification results, the levels of glucomannan, viscosity, concentration of calcium oxalate and brightness respectively are $84.37 \%, 13750$ c.Ps, $0.064 \%$, and 60.38 .

Next observation is required to study that ultrasonic maceration method is faster by using less solvent and higher levels of response values of glucomannan, viscosity and good acceptance of brightness with lower levels of oxalic acid value compare with conventional maceration method.

For future study, it is recommended tha a scale up research for coventional maceration needed to be examine due to easy application for a big amount of the product, more over, advance experiment for ultrasonic methode also need to explore to hold down the high cost of ultrasonic machine procurement.

\section{REFERENCES}

[1] Kohyama, K., H. Lida and K. Nishinari. 1993. A mixed system composed of different molecular weights konjac glucomannan and kappa carrageenan: large deformation and dynamic viscoelastic study, Food Hydrocolloids, 7 (3): 213-226
[2] Faridah A, "Optimasi Pemurnian Glukomanan dari Umbi Porang (Amorphophallus muelleri) dan Aplikasinya pada Pembuatan Mi Komposit" Disertasi, Teknologi Hasil Pertanian, Universitas Brawijaya, 2012.

[3] T. Gamse, Liquid-liquid extraction and solid-liquid extraction. Institute of thermal process and enviromental engineering, Graz University of Technology, 2002.

[4] U.S Patent 3973008. 1993. Konjac Mannan. http://www.patentstorm.com. 27 Maret 2009

[5] E. Ramadhan and A.H. Phaza, "The effect of ethanol, temperature and stage numberconcentration on ginger oleoresin extraction using batch," Thesis, Technic Faculty, Diponegoro University. Indonesia, 2007

[6] N. I. Smirnova, N. M. Mestechkina and V.D. Shcherbukhin, "Localization of Acetyl Groups in the Macromolecule of Glucomannan Obtained from Roots of Eremurus zangezuricus," Bach Institute of Biochemistry, Russian Academy of Sciences, Leninskii pr. 33, Moscow, 119071, Rusia. 2002

[7] Chan and Albert, The World of Food Science Konjac, Part I. Cultivation to Commercialization of Component. New York : 2008.

[8] T.J. Mason, L. Paniwnyk, and J.P. Lorimer, "The use of ultrasound in foodtechnology", Ultrasonics Sonochemistry, vol.3, pp. S253-S260, 1996.

[9] L. Paniwnyk, H. Cai, S. Albu, T.J. Mason, and R. Cole, "The enhancement and scale up of the extraction of anti-oxidants from Rosmarinus officinalis using ultrasound," Ultrasonics Sonochemistry, vol.16, pp. 287-292, 2009.

[10] M. Kazemi, R. Karim, H. Mirhosseini, and A. A. Hamid, "Optimization of pulsed ultrasound-assisted technique for extraction of phenolics from pomegranate peel of Malas variety: Punicalagin and hydroxybenzoic acids," Food Chemistry, vol. 206, pp. 156-166, 2016.

[11] D. Pradal, P. Vauchel, S. Decossin, P. Dhulster, and K. Dimitrov, "Kinetics of ultrasound-assisted extraction of antioxidant polyphenols from food by-products: Extraction and energy consumption optimization," Ultrasonics Sonochemistry, vol. 32, pp. 137-146, 2016.

[12] A-G. Sicaire, M. A. Vian, F. Fine, P. Carré, and S. Tostain, "Farid Chemat Ultrasound induced green solvent extraction of oil from oleaginous seeds," Ultrasonics Sonochemistry, vol. 31, pp. 319-329, 2016.

[13] G. Cuoco, C. Mathe, P. Archier, C. Farid and C. Vieillescazes. "A multivariate study of the performance of an ultrasound-assisted madder dyes extraction and characterization by liquid chromatography-photodiode array detection," Ultrasonics Sonochemistry, vol. 16, pp. 75-82, 2009.

[14] D-Y. Zhang, Y. Wan, J-Y. Xu, G-H Wu, L. Li, and X-H. Yao, "Ultrasound extraction of polysaccharides from mulberry leaves and their effect on enhancing antioxidant activity," Carbohydrate Polymers, vol. 137, pp. 473-479, 2016.

[15] W Wang, X. Ma, Y. Xu, Y. Cao, Z. Jiang, T. Ding, X. Ye, and D. Liu, "Ultrasound-assisted heating extraction of pectin from grapefruit peel: Optimization and comparison with the conventional method," Food Chemistry, vol.178, pp. 106-114, 2015.

[16] N. Sugiyama, H. Shimahara, and T. Andoh, "Studies on mannan and related compounds. I. the purification of konjac mannan", Buletin ofthe Chemical Society of Japan, vol.45, pp.561-563, 1972.

[17] AOAC, Official methods of analysis, Washington DC, USA:Association of official analytical chemists, 1995.

[18] C. Zapata, E. Deleens, S. Chaillou, and C. Magne, "Partitioning andmobilization of starch and $\mathrm{N}$ reserve in grapevine (Vitis vinifera L.)," Journal of Plant Physiology, vol.161, pp. 1031-1040, 2004.

[19] U.J. Ukpabi, and J.I. Ejidoh, "Effect of deep oil frying on the oxalate contentand the degree of Itching of cocoyams (Xanthosoma and Colocasia spp). Technical Paper presented at the 5th Annual Conference of The Agricultural Society of Nigeria, Federal University of Technology, Owerri, Nigeria, 3-6 Sept 1989.

[20] L. Peiying, Z. Shenglin, Z. Guohua, C. Yan, O. Huaxue, H. Mei, W. Zhongfeng, X. Wei, and P. Hongyi, Professional Standart of The Peoeple'Republic of China for Konjac Flour. NY/T : 494-2002.

[21] Faridah. A, Simon B.. Optimization of Multilevel Ethanol Leaching Process of Porang Flour (Amorphophallus muelleri) Using Response Surface Methodology. International Journal on Advanced Science Engineering Information Technology, vol. 3 (2), pp. 74-80, 2013.

[22] R. A. Destryana, "Optimasi Kondisi Ekstraksi-Saponifikasi Satu Tahap untuk Mendapatkan Asam Lemak Tak Jenuh Majemuk Kaya 
Asam Linoleat dan Asam $\alpha$-Linolenat dari Kedelai Varietas Unggul," tesis, Fakultas Teknologi Pertanian, Universitas Brawijaya, 2010.

[23] J. Xu, W. Wang, H. Liang, Q. Zhang, and Q. Li, "Optimization of ionic liquid based ultrasonic assisted extraction of antioxidant compounds from Curcuma longa L. using response surface methodology," Industrial Crops and Products, vol. 76, pp. 487-493, 2015.

[24] T. Belwal, P. Dhyani, I. D. Bhatt, R. S. Rawal, and V. Pande, "Optimization extraction conditions for improving phenolic content and antioxidant activity in Berberis asiatica fruits using response surface methodology (RSM)," Food Chemistry, vol. 207, pp. 115124, 2016.

[25] Y. Pan, J. Zhang, T. Shen, Z-T. Zuo, H. Jin, Y-Z. Wang,W-Y. Li, "Optimization of ultrasonic extraction by response surface methodology combined with ultrafast liquid chromatographye ultraviolet method for determination of four iridoids in Gentiana rigescens," journal of food and drug analysis, vol. 23, pp. 529-537, 2015.

[26] Q. Zhao, J. F. Kennedy, X. Wang, X. Yuan, B. Zhao, Y. Peng and Y. Huang. "Optimization of ultrasonic circulating extraction of polysaccharides from Asparagus officinalis using response surface methodology," International Journal of Biological Macromolecules, vol. 49, pp. 181-187, 2011.

[27] K. Shelke, J. W. Dick, Y. F. Holm and K. S. Loo. "Chinese wet noodle formulation: a response surface methodology study," Cereal Chemistry, vol. 67 (4), pp. 338-342, 1990.

[28] A. Tomšik, B. Pavlic', J. Vladic', M. Ramic', J. Brindza, and S. Vidovic, "Optimization of ultrasound-assisted extraction of bioactive compounds from wild garlic (Allium ursinum L.)," Ultrasonics Sonochemistry, vol. 29, pp. 502-511, 2016.

[29] U. N. Wanasundara and F. Shahidi. "Concentration of omega-3 polyunsaturated fatty acids of seal bubbler oil by urea complexation: optimization of reactions conditions," Food Chemistry, vol. 65, pp. 41-49, 1999.

[30] J. Wu, R. E. Aluko and H. Corke. "Partial least-squares regression study of the effects of wheat flour composition, protein and starch quality characteristics on oil content of steamed-and-fried instant noodles," Journal of Cereal Science, vol. 44, pp. 117-126, 2006.

[31] J. W. Povey and J. McClements. "Ultrasonics in food engineering. introduction and experimental methods," Journal of Food English, vol. 8, pp. 217-245, 1988 .

[32] (Salisova, Toma and Mason, 1997).....tidak dapat spy dihapus dari makalah (lihat terjemahan dr pak mon

[33] Takigami, S. 2000. Handbook of Hydrocolloids; Konjak Mannan, CRC Press. Washington DC.

[34] M. Izydorczyk, W. C. Steve and W. Qi, Polysaccharide Gums: Structures, Functional Properties, and Applications, In Cui, Steve W (Ed), Food Carbohydrates : Chemistry, Physical Properties, and Applications. Boca Raton : CRC Press Taylor \& Francis Group, p. 307-352, 2005.

[35] A. D. Kurniawati, "Pengaruh Tingkat Pencucian dan Lama Kontak dengan EtanolTerhadap Sifat Fisik dan Kimia Tepung Porang," tesis, Fakultas Teknologi Pertanian, Universitas Brawijaya, 2010.

[36] K. Gokduman, "Effects of $\mathrm{H} 2 \mathrm{O} 2$ Bleaching on Human Dentin and Enamel Microstructure and Function," thesis, Middle East Technical University, 2005.

[37] F.J. Keil, Modeling of process intensification, WILEY-VCH Verlag GmbH \& Co, KgaA, Weinheim, 2007.

[38] F. Liu, X. Luo and X. Lin. "Adsorption of tannin from aqueous solution by deacetylated konjac glucomannan," Journal of Hazardous Materials, vol. 178, pp. 844-850, 2010.

[39] J. R. D. David, R. H. Graves and V. R. Carison, Aseptic Processing and Packaging of Food, New York : CRC Press. Boca Raton, p. 2131, 1996.

[40] M. Shimizu, and H. Shimahara (2004). Method Of selective separation of konjacfluor from the tubers of Amorphophallus konjac. [Online], http://codex.foodnara.go.kr/lib/base_down.jsp?dr=eu\&fn $=$ konjac\% $\%$ gum.pdf

[41] P. V. Sengbusch (2008). Crystalline Inclusions, [Online], www.biologie.uni-humburg.de/b-online/e04/kristall.htm. 